\title{
Presence, Mode of Action, and Application of Pathway Specific Transcription Factors in Aspergillus Biosynthetic Gene Clusters
}

\author{
Wenjie Wang ${ }^{1,2} \mathbb{D}$, Yuchao Yu ${ }^{1}$, Nancy P. Keller ${ }^{2,3, *(\mathbb{D})}$ and Pinmei Wang ${ }^{1, *(\mathbb{D}}$ \\ 1 Ocean College, Zhejiang University, Zhoushan 316021, China; 21534024@zju.edu.cn (W.W.); \\ yuyuchao@zju.edu.cn (Y.Y.) \\ 2 Department of Medical Microbiology and Immunology, University of Wisconsin-Madison, \\ Madison, WI 53706, USA \\ 3 Department of Bacteriology, University of Wisconsin-Madison, Madison, WI 53706, USA \\ * Correspondence: npkeller@wisc.edu (N.P.K.); wangpinmei@zju.edu.cn (P.W.)
}

Citation: Wang, W.; Yu, Y.; Keller, N.P.; Wang, P. Presence, Mode of Action, and Application of Pathway Specific Transcription Factors in Aspergillus Biosynthetic Gene Clusters. Int. J. Mol. Sci. 2021, 22, 8709. https://doi.org/10.3390/ ijms 22168709

Academic Editor: Gabriel Santpere

Received: 28 July 2021

Accepted: 10 August 2021

Published: 13 August 2021

Publisher's Note: MDPI stays neutral with regard to jurisdictional claims in published maps and institutional affiliations.

Copyright: (C) 2021 by the authors. Licensee MDPI, Basel, Switzerland This article is an open access article distributed under the terms and conditions of the Creative Commons Attribution (CC BY) license (https:// creativecommons.org/licenses/by/ $4.0 /)$

\begin{abstract}
Fungal secondary metabolites are renowned toxins as well as valuable sources of antibiotics, cholesterol-lowering drugs, and immunosuppressants; hence, great efforts were levied to understand how these compounds are genetically regulated. The genes encoding for the enzymes required for synthesizing secondary metabolites are arranged in biosynthetic gene clusters (BGCs). Often, BGCs contain a pathway specific transcription factor (PSTF), a valuable tool in shutting down or turning up production of the BGC product. In this review, we present an in-depth view of PSTFs by examining over 40 characterized BGCs in the well-studied fungal species Aspergillus nidulans and Aspergillus fumigatus. Herein, we find BGC size is a predictor for presence of PSTFs, consider the number and the relative location of PSTF in regard to the cluster(s) regulated, discuss the function and the evolution of PSTFs, and present application strategies for pathway specific activation of cryptic BGCs.
\end{abstract}

Keywords: pathway specific transcription factor; transcription factor; Aspergillus; regulation; evolution

\section{Introduction}

Secondary metabolites (SMs) in fungi, also known as natural products, are present and synthesized in ecologically diverse species [1]. In fungi, SMs can provide self-protection and act as mediators for communication with other organisms or as virulence factors during pathogenic interactions with plants and animals [2-6]. Many SMs were proven to be associated with potentially useful biologic activities [7,8]. Further, some SMs are able to promote health and longevity [9].

Global aging and the variety of both infectious and non-infectious illnesses created an urgent need for discovery of new drug leads. Over the last 90 years, medicinal properties of fungal SMs, such as penicillin, cyclosporin, and statins, were utilized for various health therapies [10-12]. However, thus far, only a small subset of fungal SMs is characterized, despite the realization that fungi contain 100,000 s to millions of SM biosynthetic gene clusters (BGCs) [1,4]. The growing interest in fungal SMs is to discover new drugs and to take control of their production. Therefore, novel solutions of activating/regulating "cryptic" BGCs must be developed $[13,14]$. Hence, an important goal in mining fungal SMs is to characterize the molecular mechanisms of their production [15].

Aspergillus spp., with over 330 species, represents a major fungal genus with potent SM arsenal [4]. Aspergillus SMs are usually derived from polyketide synthases (PKSs), nonribosomal peptide synthetases (NRPSs), PKS/NRPS hybrids, terpene cyclases (TCs), dimethylallyltryptophan synthases (DMATSs), and isocyanide synthases (ICSs) $[8,16]$. Typically, a BGC is minimally composed of a synthase that uses primary metabolites to form carbon backbone that is further modified by tailoring enzymes, such as methyltransferases, P450 monooxygenases, hydroxylases, and epimerases [4]. Some BGCs contain a gene that encodes a protein involved in resistance/protection mechanisms to mitigate the toxic 
property of the SM [2]. Moreover, some BGCs contain a pathway specific transcription factor (PSTF) that specifically regulates expression of the genes within the BGC [17].

Transcription factors (TFs) are sequence-specific DNA-binding proteins required to modulate gene expression [18,19]. Recent advances shed light on hierarchical levels of SM transcriptional elements by highlighting the role of global regulators (e.g., the Velvet complex $[20,21]$ ), stress response regulators (e.g., PacC mediating fungal response to $\mathrm{pH}$ [22]), epigenetic regulators (e.g., the COMPASS complex in A. nidulans [23,24]), as well as a variety of TFs including pathway specific transcription factors (PSTFs). Whereas all of these elements are utilized for genome mining of fungal BGCs, the use of PSTFs presents the most mechanistically clear approach. However, in many cases, PSTF overexpression does not result in successful BGC activation [25]. Therefore, understanding how PSTFs regulate their biosynthetic genes is critical to the development of new strategies to discover "cryptic" SMs as potential drug molecules.

For a better understanding of PSTFs, it is essential to know the entire repertoire of PSTFs in a species. Although no one species has the entirety of its BGCs characterized, two Aspergillus species, A. nidulans and A. fumigatus, are closing in a full analysis with 28 defined BGCs in the former [26,27] and 18 defined BGCs in the latter [4,28-30]. In this review, we examine these two model fungi and identify which BGCs contain PSTFs, characterize known regulatory mechanisms of each PSTF, and present recommendations on how to better utilize PSTFs for the discovery of novel SMs.

\section{Occurrence and Types of Pathway Specific Transcription Factors}

Currently, 31 core synthase genes contained in 28 BGCs in A. nidulans (Table 2) and 23 core synthase genes contained in 18 BGCs in A. fumigatus (Table 3) are identified along with their downstream SMs. Some BGCs contain more than one synthase gene, e.g., inp $A$ and $\operatorname{inp} B$ are two NRPS genes in A. nidulans fellutamide B BGC [31], and fgaPT1 (DMATS), pes1 (NRPS), and pesL (NRPS) are essential for the production of fumigaclavine $\mathrm{C}$ in $A$. fumigatus [32,33]. Among these known BGCs, 12 BGCs (42.3\%) contain 16 PSTFs in $A$. nidulans, and 10 BGCs (55.6\%) contain 12 PSTFs in A. fumigatus.

The number of genes that are involved in the production of SMs can vary greatly. Some SMs need only a single gene, e.g., PKS8 is a stand-alone gene in Fusarium graminearum responsible for production of gibepyrones and prolipyrone B [34]. Most SMs need the coordinated involvement of few to many gene products for the assembly of the BGC product [35]. For example, the alternariol cluster of $A$. nidulans comprises two genes, a non-reducing PKS gene $p k g A$ and a $\beta$-lactamase-type thioesterase gene $p k g B$ [36], while the sterigmatocystin cluster of $A$. nidulans consists of 25 genes [37]. The size of the BGC is related to the occurrence of PSTF. In A. nidulans and A. fumigatus, most PSTFs are located in BGCs with more than five genes. Among the BGCs with more than five genes, more than two third of them contain PSTFs-12 out of $15(80.0 \%)$ BGCs in A. nidulans and 9 out of 14 (64.3\%) BGCs in A. fumigatus (Table 1). Possibly, this association of PSTF with larger BGC underlies a need for co-regulation of multiple genes that cannot be achieved by broader cis-regulatory networks.

Table 1. Occurrence of PSTF in different size of BGCs in A. nidulans and A. fumigatus.

\begin{tabular}{ccc}
\hline & BGCs & PSTF-Containing BGCs \\
\hline $\begin{array}{c}\text { Aspergillus nidulans } \\
\text { In total }\end{array}$ & 28 & 12 \\
\hline Genes $\leq 5$ & 13 & 0 \\
Genes $>5$ & 15 & 12 \\
\hline Aspergillus fumigatus & & 10 \\
In total & 18 & 1 \\
\hline Genes $\leq 5$ & 4 & 9 \\
Genes $>5$ & 14 &
\end{tabular}

$\overline{\mathrm{BGCs}}=$ biosynthetic gene clusters, PSTF = pathway specific transcription factor. 
TFs can be classed into families based on their DNA-binding domains (DBDs), including 37 PFAM families, and the largest class of fungal-specific domains is the zinc-cluster superfamily [19]. In A. nidulans, PSTFs belong to three families of TF DBDs-Zn(II) $)_{2} \mathrm{Cys}_{6}$ type, $\mathrm{C} 2 \mathrm{H} 2$ type, and Myb-like DNA-binding domain type-while several PSTFs do not have a conserved domain, and two contain fungal specific transcription factor domains (Table 2). In A. fumigatus, PSTFs belong to two families of TF DBD-Zn(II) ${ }_{2} \mathrm{Cys}_{6}$ type and bZIP type-while TpcD is a homolog of AflS without a conserved domain (Table 3). AflS is a PSTF without a conserved domain but has its critical role in the aflatoxin/sterigmatocystin (AF/ST) biosynthetic pathway as a co-activator of AflR [38]. However, other PSTFs without a conserved domain have varying functions, which are discussed later. Four types of PSTFs are involved in the BGCs with six types of synthase genes (NRPS, PKS, PKS/NRPS hybrid, DMATS, TC, and ICS) (Tables 2 and 3). We found no significant relationship between BGC types and PSTF types.

Table 2. Known secondary metabolites and their pathway specific transcription factors in A. nidulans.

\begin{tabular}{|c|c|c|c|c|c|c|c|}
\hline SM & Backbone Gene & $\begin{array}{c}\text { Backbone Gene } \\
\text { Type }\end{array}$ & Gene Number & $\begin{array}{l}\text { PSTF } \\
\text { Number }\end{array}$ & PSTF & PSTF Type & Reference \\
\hline \multirow{3}{*}{$\begin{array}{l}\text { 2,4-dihydroxy-3-methyl-6-(2- } \\
\text { oxopropyl)benzaldehyde } \\
\text { (DHMBA)/felinone A } \\
\text { 6-hydroxy-7-methyl-3- } \\
\text { nonylisoquinoline-5,8-dione } \\
\text { Alternariol/isocoumarins }\end{array}$} & $\begin{array}{l}d b a I / p k e A \\
\text { (AN7903) }\end{array}$ & NR-PKS & 9 & 2 & $d b a A, d b a G$ & $\begin{array}{l}\mathrm{Zn}(\mathrm{II})_{2} \mathrm{Cys}_{6}, \text { no } \\
\text { conserved } \\
\text { domain }^{1}\end{array}$ & {$[39,40]$} \\
\hline & pkiA (AN3386) & NR-PKS & 3 & 0 & / & / & [36] \\
\hline & $\operatorname{pkg} A(\mathrm{AN7071)}$ & NR-PKS & 2 & 0 & / & $\mathrm{Zn}(\mathrm{III})_{2} \mathrm{Cys}_{6}$ & [36] \\
\hline Aspercryptins & $\begin{array}{l}a t n A \text { (AN7884), } \\
p k b A \text { (AN6448) }\end{array}$ & NRPS, NR-PKS & $14+7^{2}$ & $1+1^{3}$ & $\operatorname{atnN}, \operatorname{cic} D$ & \multirow{2}{*}{$\begin{array}{c}\text { Myb-like } \\
\text { DNA-binding } \\
\text { domain } \\
\mathrm{Zn}(\mathrm{II})_{2} \mathrm{Cys}_{6} \\
\mathrm{C} 2 \mathrm{H} 2 \text { type zinc } \\
\text { finger }\end{array}$} & {$[41,42]$} \\
\hline Asperfuranone & $\begin{array}{l}\text { afoE (AN1034), } \\
\text { afoG (AN1036) }\end{array}$ & $\begin{array}{l}\text { NR-PKS, } \\
\text { HR-PKS }\end{array}$ & 7 & $1+1^{3}$ & afo $A, s c p R$ & & {$[43,44]$} \\
\hline (+)-Asperlin & $\operatorname{aln} A(\mathrm{AN} 11191)$ & HR-PKS & 10 & 1 & $\operatorname{aln} R$ & \multirow{2}{*}{$\mathrm{Zn}(\mathrm{II})_{2} \mathrm{Cys}_{6}$} & [45] \\
\hline Aspernidine A & $p k f A(\mathrm{AN} 3230)$ & NR-PKS & 6 & 0 & / & & {$[46]$} \\
\hline Asperniduglene A1 and A2 & $\begin{array}{l}\text { sdgA/pkjA } \\
\text { (AN1784) }\end{array}$ & HR-PKS & 4 & 0 & / & / & {$[47]$} \\
\hline Asperthecin & aptA (AN6000) & NR-PKS & 3 & 0 & / & / & [48] \\
\hline Aspyridone A and B & $\operatorname{apdA}(\mathrm{AN} 8412)$ & $\begin{array}{l}\text { PKS/NRPS } \\
\text { hybrid }\end{array}$ & 8 & 1 & $\operatorname{apd} R$ & $\mathrm{Zn}(\mathrm{II})_{2} \mathrm{Cys}_{6}$ & {$[49]$} \\
\hline Austinol/dehydroaustinol & ausA (AN8383) & NR-PKS & $4+10^{2}$ & 0 & / & Myb-like & [50] \\
\hline Cichorine & $p k b A$ (AN6448) & NR-PKS & 7 & 1 & $\operatorname{cicD}$ & $\begin{array}{l}\text { DNA-binding } \\
\text { domain }\end{array}$ & {$[51]$} \\
\hline Echinocandin B & aniA & NRPS & 12 & 0 & / & \multirow[t]{2}{*}{ / } & {$[52]$} \\
\hline Emericellamides & $\begin{array}{l}\text { easA (AN2545), } \\
\text { easB (AN2547) }\end{array}$ & NRPS, HR-PKS & 4 & 0 & / & & {$[53]$} \\
\hline ent-pimara-8(14),15-diene & AN1594 & TC & 7 & 1 & $p b c R$ & $\mathrm{Zn}(\mathrm{II})_{2} \mathrm{Cys}_{6}$ & [54] \\
\hline $\begin{array}{l}\text { F-9775 A and B/violaceol I and } \\
\text { II/orsellinic acid }\end{array}$ & ors A (AN7909) & NR-PKS & 3 & 0 & / & \multirow{3}{*}{$\begin{array}{c}/ \\
\mathrm{C} 2 \mathrm{H} 2 \text { type zinc } \\
\text { finger }\end{array}$} & {$[55,56]$} \\
\hline Fellutamide B & $\begin{array}{l}\operatorname{inp} A(\mathrm{AN} 3495) \\
\operatorname{inpB}(\mathrm{AN} 3496)\end{array}$ & NRPS, NRPS & 6 & 1 & $\operatorname{scp} R$ & & {$[31]$} \\
\hline Ferricrocin & sidC (AN0607) & NRPS & 3 & 0 & / & & [57] \\
\hline $\begin{array}{l}\text { Grey-brown conidiophore } \\
\text { pigment }\end{array}$ & ivoA (AN10576) & NRPS & $2+1^{2}$ & 0 & / & \multirow{2}{*}{$\begin{array}{l}\text { / } \\
\text { Fungal specific } \\
\text { transcription } \\
\text { factor domain }\end{array}$} & [58] \\
\hline $4^{\prime}$-Methoxyviridicatin & asqK (AN9226) & NRPS & 14 & 1 & $\operatorname{asq} A$ & & [59] \\
\hline \multicolumn{2}{|c|}{ Microperfuranone/dehydromicropenficedrtiAite3396) } & NRPS-like & 3 & 0 & / & \multirow{2}{*}{$\begin{array}{c}\mathrm{Zn}(\mathrm{II})_{2} \mathrm{Cys}_{6}, \text { no } \\
\text { conserved } \\
\text { domain }^{1}\end{array}$} & {$[60]$} \\
\hline $\begin{array}{l}\text { Xanthones, Arugosin A and H, } \\
\text { Sanghaspirodins A and B }\end{array}$ & $m d p G(\mathrm{AN} 0150)$ & NR-PKS & $1+2+10^{2}$ & 2 & $m d p E, m d p A$ & & {$[23,61-63]$} \\
\hline Nidulanin A & $n l s A(\mathrm{AN} 1242)$ & NRPS & $1+1^{2}$ & 0 & / & / & [64] \\
\hline Penicillin & $\operatorname{acv} A(\mathrm{AN} 2621)$ & NRPS & 3 & 0 & / & / & [65] \\
\hline Sterigmatocystin & $\begin{array}{c}s t c A / p k s S T \\
(\mathrm{AN7825)}\end{array}$ & NR-PKS & 25 & 2 & $\begin{array}{c}\text { aflR, } \\
\text { aflS /aflJ }\end{array}$ & $\begin{array}{l}\mathrm{Zn}(\mathrm{II})_{2} \mathrm{Cys}_{6}, \text { no } \\
\text { conserved } \\
\text { domain }^{1}\end{array}$ & {$[37,64]$} \\
\hline Terrequinone A & tdiA (AN8513) & NRPS-like & 5 & 0 & / & I & {$[66]$} \\
\hline Viridicatumtoxin ${ }^{5}$ & vrtA & NR-PKS & 13 & 2 & vrtR1, vrtR2 & $\begin{array}{l}\text { Fungal specific } \\
\text { transcription } \\
\text { factor domain }{ }^{4} \\
\mathrm{Zn}(\mathrm{II})_{2} \mathrm{Cys}_{6}\end{array}$ & {$[67,68]$} \\
\hline YWA1 & $w A(\mathrm{AN} 8209)$ & NR-PKS & 2 & 0 & / & / & [69] \\
\hline
\end{tabular}

SM = secondary metabolite, PSTF = pathway specific transcription factor, NRPS = nonribosomal peptide synthetase, HR-PKS = highly reducing polyketide synthase, NR-PKS = non-reducing polyketide synthase, TC = terpene cyclase. ${ }^{1}$ No conserved domain means PSTF without conserved domain. ${ }^{2}$ " $\mathrm{x}+\mathrm{x}(+\mathrm{x})$ " means biosynthesis genes are not all located in a single cluster but in at least two chromosomal sites. ${ }^{3}$ Two PSTFs are not located in a single cluster. ${ }^{4}$ This domain is a fungal transcription factor regulatory middle homology region, which is present in the large family of fungal zinc cluster TFs. The regulatory function of this type of region is still unclear. ${ }^{5}$ Gene designations are based on those from Penicillium aethiopicum [67]. 
Table 3. Known secondary metabolites and their pathway specific transcription factors in A. fumigatus.

\begin{tabular}{|c|c|c|c|c|c|c|c|}
\hline SM & Backbone Gene & $\begin{array}{c}\text { Backbone Gene } \\
\text { Type }\end{array}$ & Gene Number & PSTF Number & PSTF & PSTF Type & Reference \\
\hline DHN-melanin ${ }^{1}$ & $\begin{array}{c}p k s P / a l b 1 \\
\text { (Afu2g17600) }\end{array}$ & NR-PKS & 6 & 0 & / & / & {$[70,71]$} \\
\hline Endocrocin/trypacidin & $\begin{array}{l}\text { encA (Afu4g00210), } \\
\text { tpcC (Afu4g14560) }\end{array}$ & $\begin{array}{l}\text { NR-PKS, } \\
\text { NR-PKS }\end{array}$ & $4+13^{2}$ & 2 & $t p c E, t p c D$ & $\begin{array}{c}\mathrm{Zn}(\mathrm{II})_{2} \mathrm{Cys}_{6}, \\
\text { no } \\
\text { conserved } \\
\text { domain }^{3}\end{array}$ & {$[72]$} \\
\hline Ferricrocin $/$ TAFC $^{4}$ & $\begin{array}{l}\text { sidC (Afu1g17200), } \\
\text { sidD (Afu3g03420) }\end{array}$ & NRPS, NRPS & $1+1+3^{2}$ & 0 & / & / & {$[73,74]$} \\
\hline Fumagillin & $\begin{array}{c}f m a B / f m a-P K S \\
\text { (Afu8g00370) }\end{array}$ & HR-PKS & 10 & 1 & fapR/fumR & $\mathrm{Zn}(\mathrm{II})_{2} \mathrm{Cys}_{6}$ & [75-77] \\
\hline Fumigaclavine $\mathrm{C}$ & $\begin{array}{c}\text { fgaPT1 (Afu2g17990), } \\
\text { pes1/pesB } \\
\text { (Afu1g10380), } \\
\text { pesL/fqzC } \\
\text { (Afu6g12050) }\end{array}$ & $\begin{array}{l}\text { DMATS, NRPS, } \\
\text { NRPS }\end{array}$ & $11+1+1^{2}$ & 0 & / & / & {$[32,33]$} \\
\hline Fumigermin & fgnA (Afu1g01010) & PR-PKS & 5 & 0 & / & / & [28] \\
\hline Fumihopaside A and B & $\begin{array}{c}\text { afumA } \\
\text { (AFUB_071550) }\end{array}$ & $\mathrm{TC}$ & 4 & 1 & afumD & $\mathrm{Zn}(\mathrm{II})_{2} \mathrm{Cys}_{6}$ & [29] \\
\hline Fumiquinazolines & pesM (Afu6g12080) & NRPS & 4 & 0 & / & / & {$[33,78]$} \\
\hline Fumisoquins/fumipyrrole & $\begin{array}{c}f s q F / f m p E \\
(\mathrm{Afu} 6 \mathrm{~g} 03480)\end{array}$ & NRPS-like & 7 & 1 & $f_{s} q A / f m p R$ & $\mathrm{Zn}(\mathrm{II})_{2} \mathrm{Cys}_{6}$ & {$[79,80]$} \\
\hline Fumitremorgin/brevianamide F & ftmA (Afu8g00170) & NRPS & 9 & 0 & / & l & {$[81,82]$} \\
\hline Gliotoxin & gliP (Afu6g09660) & NRPS & $12+1+1^{2}$ & $1+1^{5}$ & gliZ, rglT & $\begin{array}{l}\mathrm{Zn}(\mathrm{II})_{2} \mathrm{Cys}_{6}, \\
\mathrm{Zn}(\mathrm{II})_{2} \mathrm{Cys}_{6}\end{array}$ & {$[83-86]$} \\
\hline Helvolic acid & $\begin{array}{c}\text { helA (Afu4g14770) } \\
\text { hasD/pesF }\end{array}$ & $\mathrm{TC}$ & 9 & 0 & / & $/$ & [87] \\
\hline Hexadehydroastechrome & $\begin{array}{l}\text { (Afu3g12920), hasE } \\
\text { (Afu3g12930) }\end{array}$ & NRPS, DMATS & 8 & 2 & has $A$, hasF & $\begin{array}{l}\mathrm{Zn}(\mathrm{II})_{2} \mathrm{Cys}_{6}, \\
\mathrm{Zn}(\mathrm{II})_{2} \mathrm{Cys}_{6}\end{array}$ & [88] \\
\hline Neosartoricin/fumicyclines & $\begin{array}{c}n s c A / f c c A \\
\text { (Afu7g00160) }\end{array}$ & NRPS & 6 & 1 & $n s c R$ & $\mathrm{Zn}(\mathrm{II})_{2} \mathrm{Cys}_{6}$ & [89-91] \\
\hline Psecurotin A & posA (Afu8g00540) & $\begin{array}{c}\text { PKS/NRPS } \\
\text { hybrid }\end{array}$ & 6 & 1 & fapR/fumR & $\mathrm{Zn}(\mathrm{II})_{2} \mathrm{Cys}_{6}$ & {$[77,92]$} \\
\hline Pyomelanin & $h p p D$ (Afu2g04200) ${ }^{6}$ & I & 6 & 1 & $h m g R$ & $\mathrm{Zn}(\mathrm{II})_{2} \mathrm{Cys}_{6}$ & {$[30,93]$} \\
\hline Pyripyropene A & pyr2 (Afu6g13930) & HR-PKS & 8 & 0 & j & / & {$[94]$} \\
\hline Xanthocillin & xanB (Afu5g02660) & ICS & 6 & 1 & $x a n C$ & bZIP & [16] \\
\hline
\end{tabular}

$\mathrm{SM}=$ secondary metabolite, PSTF = pathway specific transcription factor, NRPS = nonribosomal peptide synthetase, HR-PKS = highly reducing polyketide synthase, NR-PKS $=$ non-reducing polyketide synthase, PR-PKS = partially reducing polyketide synthase, DMATS = dimethylallyltryptophan synthase, $\mathrm{TC}=$ terpene cyclase, $\mathrm{ICS}=$ isocyanide synthase. ${ }^{1} \mathrm{DHN}-\mathrm{melanin}=$ dihydroxynaphthalene melanin. ${ }^{2}$ " $x+x(+x)$ " means biosynthesis genes are not all located in a single cluster but in at least two sites. ${ }^{3}$ No conserved domain means PSTF without conserved domain. ${ }^{4}$ TAFC $=$ triacetylfusarinine $C .{ }^{5}$ Two PSTFs are not located in a single cluster. ${ }^{6}$ Key enzyme gene involved in the L-tyrosine degradation pathway encoding 4-hydroxyphenylpyruvate dioxygenase.

\section{Role and Evolution of Pathway Specific Transcription Factor (PSTF)}

Of those BGCs containing PSTFs, most contain one PSTF, but there are variations, including BGCs with two PSTFs or a single PSTF that regulates more than one BGC (Table 4); examples are discussed below. Additionally, most PSTFs are positive regulators with some exceptions: one of the A. fumigatus hexadehydroastechrome BGC PSTFs, HasF, has no apparent function [88], and the second PSTF of the A. nidulans felinone A BGC, $\mathrm{DbaG}$, is a negative regulator but under the control of the positive PSTF DbaA $[39,40]$.

Table 4. Different cases in A. nidulans and A. fumigatus of distribution of PSTF in BGCs.

\begin{tabular}{|c|c|c|c|}
\hline Case Type & Aspergillus nidulans & Aspergillus fumigatus & Case in Total \\
\hline One PSTF per BGC & $6(6 \text { PSTFs }+6 \text { BGCs })^{1}$ & 5 (5 PSTFs +5 BGCs) $^{1}$ & 11 \\
\hline Two PSTFs per BGC & $4{\text { (8 PSTFs }+4 \text { BGCs })^{1}}^{1}$ & 2 (4 PSTFs +2 BGCs) $^{1}$ & 6 \\
\hline One PSTF for two BGCs & / & $1(1 \mathrm{PSTF}+2 \text { BGCs })^{1}$ & 1 \\
\hline Additional case $^{2}$ & $1(2 \text { PSTFs }+2 \text { BGCs })^{1}$ & 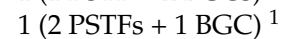 & 2 \\
\hline
\end{tabular}

BGC = biosynthetic gene cluster, PSTF = pathway specific transcription factor. ${ }^{1}$ Number of cases (number of PSTFs + number of BGCs involved). ${ }^{2}$ Additional case indicates two more complex examples: (1) two PSTFs involved in a cross talk between two BGCs; (2) two PSTFs involved in one BGC with one PSTF located outside of the cluster.

\subsection{One PSTF per BGC}

\subsubsection{PSTF with Single Conserved Function}

The basic function of the single PSTF in a single BGC is as a specific positive regulator. Overexpression of this type of PSTF is useful in inducing cryptic/low production metabo- 
lites or identifying the boundaries of the BGC. For example, inducing expression of the PSTF gene apdR activates the cryptic PKS/NRPS hybrid gene cluster to produce aspyridones A and B [49], and overexpression of the positive PSTF gene $f_{s} q A$ regulates expression of six adjacent genes, $f s q B$ to $f s q G$, and defines the boundaries of the $f s q$ cluster which is responsible for fumisoquin biosynthesis [80] (Figure 1a). Overexpression of $n s c R$ leads to isolation of a new metabolite neosartoricin [91]. The PSTF HmgR is a transcriptional activator for the genes of the tyrosine degradation cluster, which is a different pathway from DHN-melanin and produces an alternative melanin, pyomelanin [93].
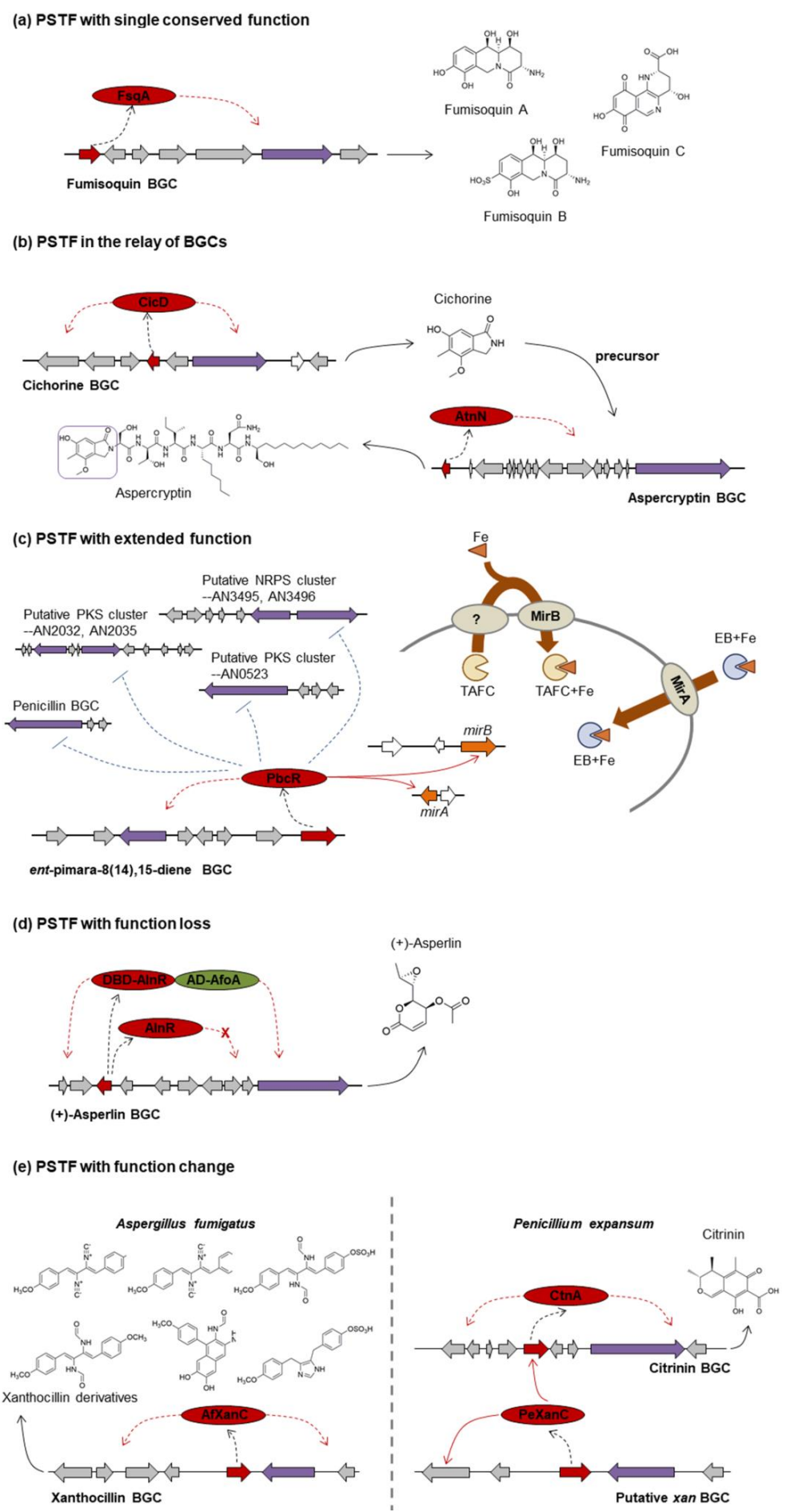

Figure 1. Examples of "one PSTF per BGC". (a) PSTF with single conserved function. (b) PSTF in the relay of BGCs. (c) PSTF with extended function. (d) PSTF with function loss. AD-AfoA (green) means 
the activation domain (AD) from AfoA. DBD-AlnR (red) means the DNA-binding domain (DBD) from AlnR. (e) PSTF with function change. Purple indicates backbone genes; red indicates positive PSTFs; grey indicates tailoring genes involved in the SM biosynthetic pathway; white indicates genes not involved in the SM biosynthetic pathway; orange indicates mir $A$ and mirB genes under the regulation of PSTF PbcR and responsible for transporting iron. The dotted black arrow indicates the process of protein translation by the PSTF gene; the solid black arrow indicates the process of SM(s) production by the BGC; the dotted red arrow indicates the positive regulation by the PSTF for all the other biosynthetic genes in the cluster; the solid red arrow indicates positive regulation by the PSTF for the specific gene; the dotted blue arrow with a stop end indicates the negative regulation by the PSTF for the whole cluster genes. (e) is based on Figure 6 in reference [95]. PSTF = pathway specific transcription factor, BGC = biosynthetic gene cluster.

\subsubsection{PSTF in the Relay of BGCs: $\operatorname{cic} D, \operatorname{atn} N$}

The cichorine BGC contains seven genes identified by a set of targeted deletions [51]. Deletion of the PSTF gene $c i c D$ eliminates the production of cichorine, which indicates that CicD is a positive PSTF. Interestingly, cichorine is the precursor of aspercryptin [41]. In other words, aspercryptin is produced by two distinct clusters that are physically separated in the genome, the cic cluster (in chromosome I) and the atn cluster (in chromosome II) (Figure 1b). The core biosynthetic gene for the cichorine pathway is a PKS, and the core biosynthetic gene for the aspercryptin cluster is an NRPS (Table 2). Similar to cicD in the cic cluster, the atn cluster also has a positive PSTF gene, $\operatorname{atnN}$, and overexpression of $\operatorname{atnN}$ leads to increased aspercryptin A1 production [42]. This raises the exciting possibility that A. nidulans uses PSTFs to regulate different SM gene clusters to expand their repertoire of natural products and tailor the SM arsenal to achieve maximum competitive advantage.

\subsubsection{PSTF with Extended Function: $p b c R$}

Overexpression of the PSTF gene $p b c R$ upregulates the transcription of seven genes in the identified cluster and leads to the production of a diterpene compound, ent-pimara8(14),15-diene [54]. Additionally, the expression levels of siderophore transporter genes mir $A$ and mirB are upregulated. Further, overexpression of $p b c R$ downregulates four other clusters (penicillin cluster, two putative PKS clusters, and one putative NRPS cluster) (Figure 1c), which might be a way for $A$. nidulans to reserve sufficient primary metabolites for cell growth or for the specific production of ent-pimara-8(14),15-diene [54]. However, the mechanism for the downregulation of these clusters in the $p b c R$ overexpression strain is still not clear, and a possible function of $p b c R$ in iron homeostasis is waiting to be explored. These studies on $p b c R$ indicate that one extending function of PSTF could be in linking with higher-level regulation system(s) or other SMs.

\subsubsection{PSTF with Function Loss: $a \ln R$}

Replacement of the promoter of PSTF gene $\operatorname{aln} R$ with the inducible alcA promoter did not result in any detectable product. However, when Grau et al. [45] fused the DNAbinding domain (DBD) of AlnR with the activation domain (AD) from AfoA, the hybrid PSTF activated transcription of the target BGC genes to obtain the antibiotic (+)-asperlin (Figure 1d). This gives an example of function loss of PSTF due to the incomplete/nonfunctional domains, which might be the cause of the failure of other studies that were unsuccessful in overexpressing PSTFs to activate cryptic BGCs.

\subsubsection{PSTF with Function Change: $x a n C$}

In A. fumigatus, overexpression of $x a n C$ upregulates the expression of all xanthocillin biosynthesis genes and increases abundance of all downstream xanthocillin derivatives [16], which indicates XanC (AfXanC) is a positive PSTF for the xan cluster. A highly conserved $x a n$ cluster with a $x a n C$ homolog $(P e x a n C)$ was identified in Penicillium expansum. Surprisingly, instead of regulating the Pexan BGC (with the exception of one gene, PexanG), PeXanC activates the citrinin PSTF gene $\operatorname{ctn} A$ and increases the production of citrinin [95] 
(Figure 1e). This divergence is partially explained by the finding that AfXanC and PeXanC recognize different DNA binding sites [95]. This gives an example of evolutionary variance and functional change of PSTF homologs.

\subsection{Two PSTFs per BGC}

In A. nidulans and A. fumigatus, one quarter of PSTF-containing BGCs have two PSTFs in a single BGC. Interestingly, instead of playing the similar function of regulating genes, one TF usually plays the predominant positive role, while the other TF plays a variant function, e.g., co-activator, negative regulator, or no function at all. Moreover, $m d p E$ and $m d p A$ present an example of a more complex regulatory scheme, as discussed below.

\subsubsection{AflR-AflS Type}

- aflR-aflS

The aflatoxin/sterigmatocystin (AF/ST) gene cluster represents one of the best characterized mycotoxin gene clusters with two PSTF genes, aflR and aflS (previously named as aflJ). AflR is a $\mathrm{Zn}(\mathrm{II})_{2} \mathrm{Cys}_{6} \mathrm{TF}$, while AflS is a TF without a conserved domain but shows some low similarity to a methyltransferase. AflR activates the transcription of most structural genes in the ST gene cluster in A. nidulans, and deletion of aflR abolishes the ST synthesis [96]. AflS plays a role in the regulation of the ST biosynthesis through interacting with AflR and is often termed as a co-activator. The $\triangle a f l S$ mutant produces reduced but detectable levels of ST [96] (Figure 2a(i)). A. flavus aflR is able to complement the A. nidulans $\triangle a f l R$ strain and restore the ST production [97]. However, A. sojae is unable to produce $\mathrm{AF} / \mathrm{ST}$ due to a functional mutation of aflR. The mutation in aflR results in a truncated protein and the failure of AflR to interact with AflS [98].

- $\quad m d p E-m d p A$

$m d p E$ and $m d p A$ encode PSTFs regulating expression of $m d p$ cluster genes responsible for the production of monodictyphenone and prenyl xanthones in A. nidulans [61,62]. MdpE is a distinct $\mathrm{Zn}(\mathrm{II})_{2} \mathrm{Cys}_{6} \mathrm{TF}$ homologous to AflR, while MdpA is a TF homologous to AflS. Inducing expression of $m d p E$, but not $m d p A$, activated expression of $m d p$ cluster genes, resulting in the production of monodictyphenone and emodin analogs [23,62]. Similar to the AflR-AflS regulation model, MdpE is the positive acting DNA binding partner, while MdpA is the co-activator in the monodictyphenone biosynthesis.

Some $m d p$ cluster genes also participate in the prenyl xanthone biosynthesis with emodin and monodictyphenone precursors for producing prenyl xanthones [61]. Unexpectedly, $m d p D$ (encoding a monooxygenase) and $m d p E$ (encoding a PSTF) are not consistently involved in monodictyphenone biosynthesis and xanthone biosynthesis. $m d p D$ is unnecessary for monodictyphenone generation but is required for xanthone synthesis, whereas $m d p E$ is necessary for monodictyphenone generation but is not required for xanthone synthesis [61]. In contrast to $m d p E$, the PSTF gene $m d p A$ is required for the synthesis of both monodictyphenone and xanthone [61] (Figure 2a(ii)).

- $\quad t p c E-t p c D$

In A. fumigatus, there is an unusual example of two physically discrete BGCs (endocrocin cluster and trypacidin cluster) generating the same SM-endocrocin [72]. The $t p c$ cluster makes use of different gene combinations to produce either endocrocin or trypacidin. Trypacidin is eliminated when only tpc cluster genes are deleted, whereas the elimination of endocrocin production needs the deletion of both tpc cluster and enc cluster genes. A homolog of AflR, TpcE, is required for regulating $t p c$ genes to produce trypacidin and endocrocin with a co-activator, $\mathrm{TpCD}$, which is an AflS homolog. No PSTF exists in the enc cluster, which contains four genes in total [72]. 
(a) AflR-AflS type

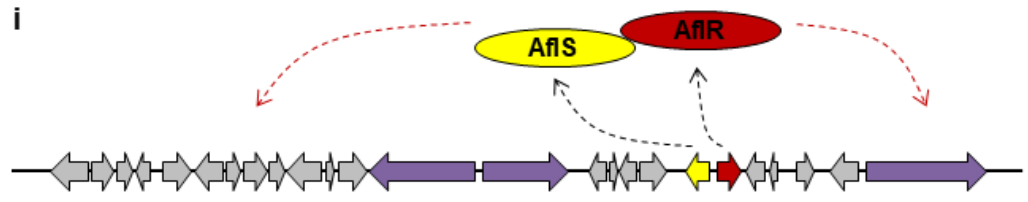

stc BGC

ii
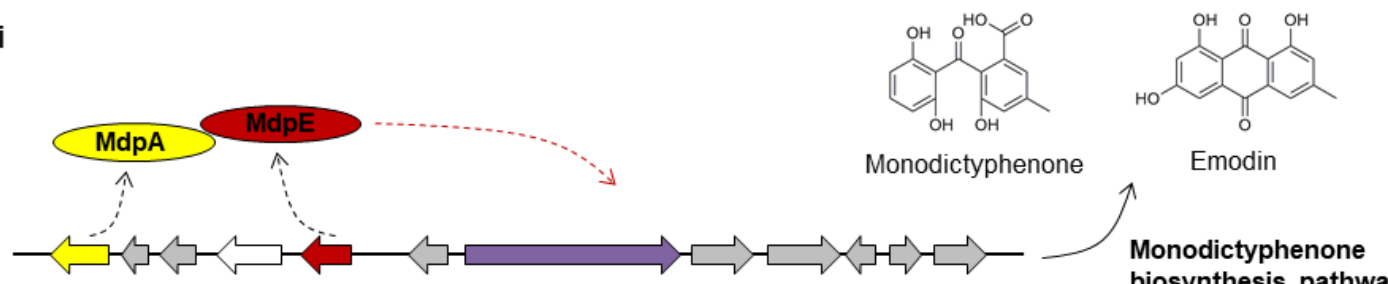

$m d p$ BGC

Chromosome VII

biosynthesis pathway

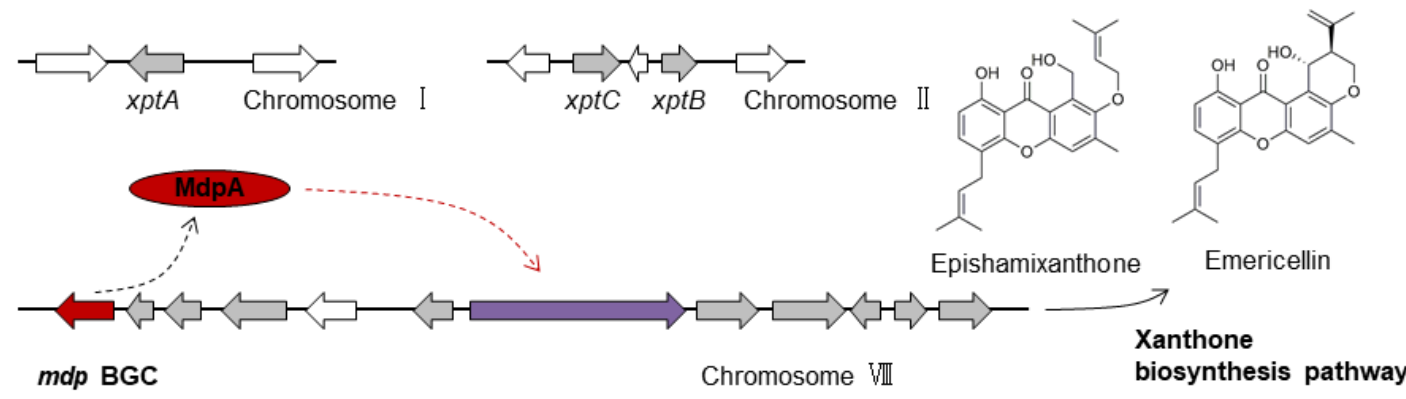

(b) Positive TF-Negative TF type

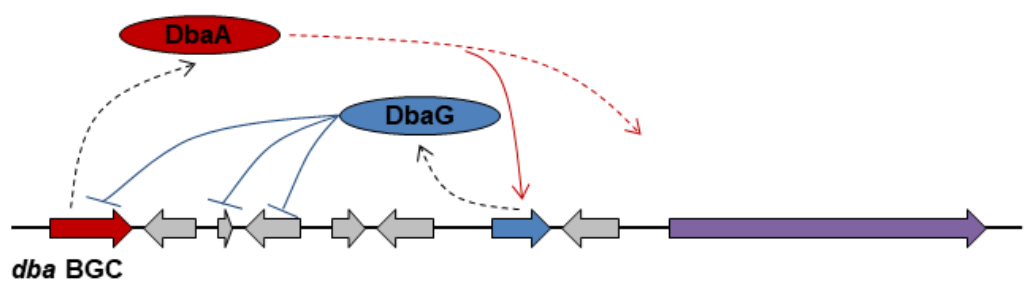

(c) Positive TF-No function TF type

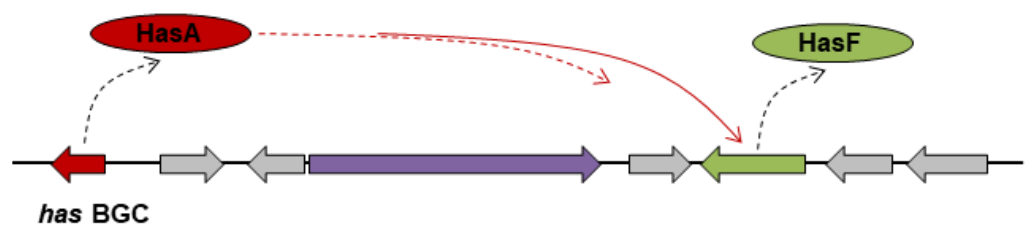

Figure 2. Examples of "two PSTFs per BGC". (a) AflR-AflS type. (i) aflR-aflS in the sterigmatocystin (ST) BGC; (ii) $m d p E$ $m d p A$ in monodictyphenone or xanthone biosynthesis. (b) Positive TF-Negative TF type. (c) Positive TF-No function TF type. Purple indicates backbone genes; red indicates positive PSTFs; yellow indicates the second PSTF gene as co-activator; 
blue indicates negative PSTF; green indicates PSTF with no function; grey indicates tailoring genes involved in the SM biosynthetic pathways; white indicates genes not involved in the SM biosynthetic pathway. The dotted black arrow indicates the process of protein translation by the PSTF gene; the solid black arrow indicates the process of SM(s) production by the BGC; the dotted red arrow indicates the positive regulation by the PSTF for all the other biosynthetic genes in the cluster; the solid red arrow indicates positive regulation by the PSTF for the specific gene; the solid blue arrow with a stop end indicates the negative regulation by the PSTF for the specific gene.

\subsubsection{Positive TF-Negative TF Type: $d b a A-d b a G$}

Overexpression of the PSTF gene $d b a A$ coordinately upregulates nine consecutive genes, which defines the boundaries of the $d b a$ cluster in $A$. nidulans to produce 2,4dihydroxy-3-methyl-6-(2-oxopropyl)benzaldehyde (DHMBA) [40]. However, overexpression of another PSTF gene in the $d b a$ cluster, $d b a G$, slightly increases the expression of one gene $(d b a F)$ but decreases the expression levels of three other genes $(d b a A, d b a C$, and $d b a D$ ) [40]. Different from positive TF DbaA, DbaG is a negative PSTF (Figure 2b). Interestingly, $d b a G$ is under control of the positive acting PSTF DbaA, suggesting a complex transcriptional control of the entire $d b a$ gene cluster.

\subsubsection{Positive TF-No Function TF Type: has A-hasF}

The $\mathrm{Zn}(\mathrm{II})_{2} \mathrm{Cys}_{6} \mathrm{TF}$ gene has $A$ was down-regulated in an A. fumigatus $\triangle l a e A$ array, leading to the hypothesis that it could be a PSTF for surrounding genes [99]. Indeed, overexpression of has $A$ results in the expression of seven adjacent genes (including the second TF hasF) responsible for the production of hexadehydroastechrome (HAS) [88]. However, loss of the second transcription factor HasF (OE::has $A \Delta$ hasF) does not result in any detectable metabolomic change compared to the OE::has $A$ strain, indicating that HasF does not affect the has pathway [88] (Figure 2c).

\subsection{One PSTF for Two BGCs: fapR}

In the telomeric region of chromosome VIII in A. fumigatus, there is a supercluster containing two intertwined BGCs that produce fumagillin [75,76] and pseurotin A [92], respectively (Figure 3). They do not share any structural genes/enzymes for their syntheses, however, fumagillin and pseurotin biosynthetic genes are physically interspersed [77]. The $\mathrm{Zn}(\mathrm{II})_{2} \mathrm{Cys}_{6}$ TF FapR (also called FumR [76]) was confirmed to regulate both pseurotin and fumagillin cluster genes [77].

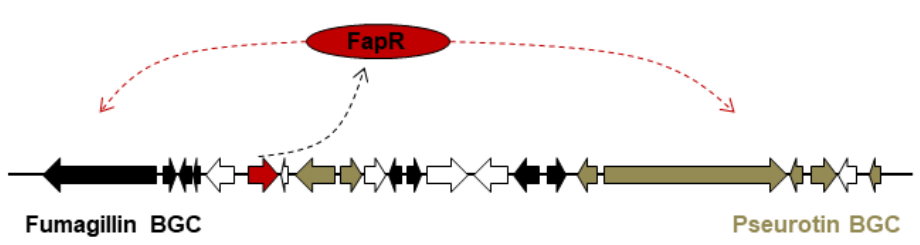

Figure 3. Model of FapR in a supercluster containing fumagillin and pseurotin biosynthetic genes. Black indicates genes involved in the fumagillin biosynthesis; brown indicates genes involved in the pseurotin biosynthesis; red indicates the positive PSTF gene fapR; white indicates genes not involved in either biosynthetic pathway. The dotted black arrow indicates the process of protein translation by the PSTF gene fapR; the dotted red arrow indicates the positive regulation by the PSTF for all the biosynthetic genes in the two clusters.

\subsection{Additional Complexities in PSTF Regulation}

\subsubsection{PSTF in Cross Talk: $s c p R-a f o A$}

In chromosome II in $A$. nidulans, the silent inp cluster contains two NRPS genes, $\operatorname{inp} A$ and $\operatorname{inp} B$, flanked by the PSTF gene $\operatorname{scpR}$. The induced expression of $s c p R$ leads to the transcriptional activation of $\operatorname{inp} A$ and $\operatorname{inp} B$, the fatty-acyl-AMP ligase gene inpC, and the transporter gene $i n p D$ but not the activation of the proteasome gene inpE or the release gene $i n p F$ [44]. No NRPS product was detected from $s c p R$ overexpression 
because $\operatorname{inpE}$ and $\operatorname{inpF}$ were confirmed in further research to be essential for the final product of inp cluster, a proteasome inhibitor fellutamide B [31]. The proteasome InpE is required for resistance to the intracellularly produced fellutamide $B$. Interestingly, instead of activating all six inp genes to produce fellutamide B, ScpR activates the silent afo cluster in chromosome VIII through activating the afo cluster PSTF gene afoA to produce the polyketide asperfuranone [44] (Figure 4a). The cross talk between ScpR and AfoA is similar to the previously mentioned regulation of the cit cluster by PeXanC in P. expansum, with both presenting instances of unexpected divergence of PSTF target pathways.

\section{(a) PSTF in cross talk}

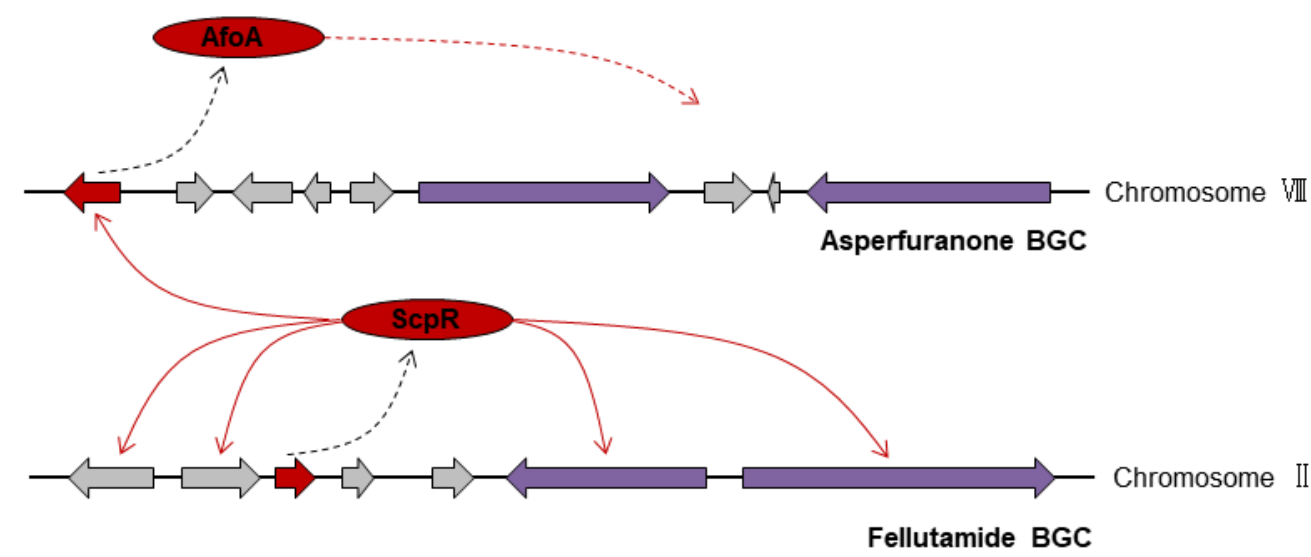

(b) In-cluster and out-of-cluster location of two PSTFs for a single BGC

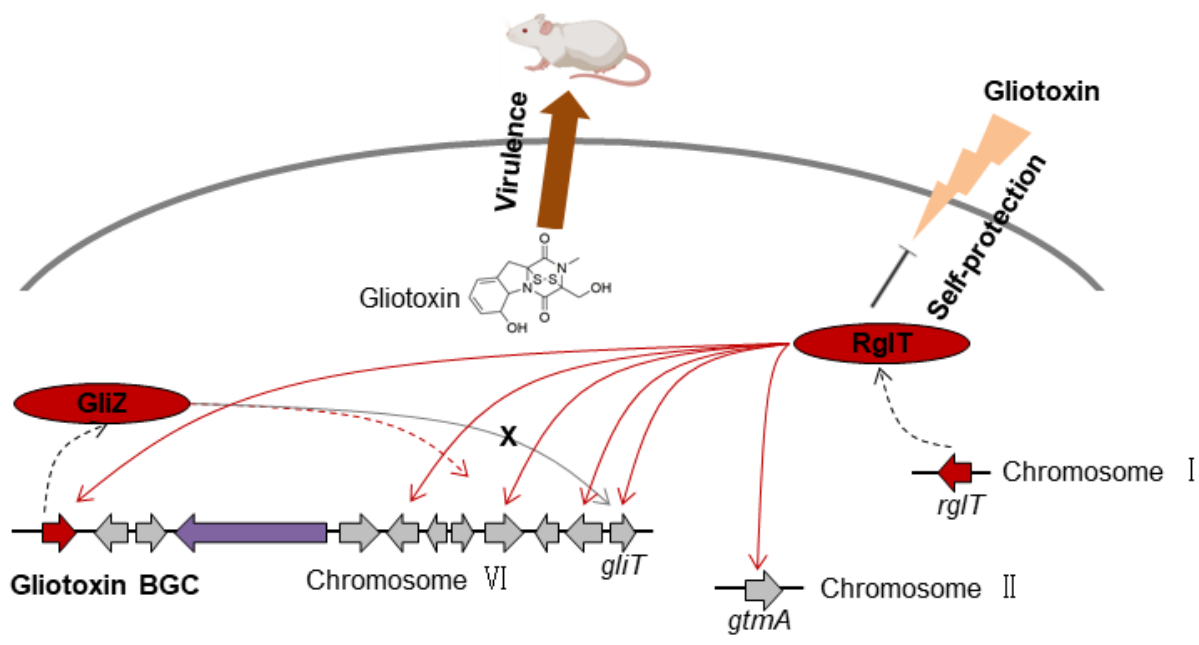

Figure 4. Examples of additional complexities in PSTF regulation. (a) PSTF in BGC cross talk. (b) In-cluster and outof-cluster locations of two PSTFs regulating a single BGC. Purple indicates backbone genes; red indicates positive PSTF genes; grey indicates tailoring genes involved in the SM biosynthetic pathways. The dotted black arrow indicates the process of protein translation by the PSTF gene; the dotted red arrow indicates the positive regulation by the PSTF for all the other biosynthetic genes in the cluster; the solid red arrow indicates positive regulation by the PSTF for the specific gene; the solid grey arrow with an " $X$ " indicates that gliT is not under the regulation of the PSTF GliZ. (a) is based on this figure in reference [44].

3.4.2. In-Cluster and Out-of-Cluster Locations of Two PSTFs for a Single BGC: gliZ and $\mathrm{rglT}$

Gliotoxin is known as a mycotoxin and a virulence factor in A. fumigatus [100]. GliZ, a positive PSTF, is indispensable for the gliotoxin biosynthesis. The overexpression of 
gliZ increases gliotoxin production, and gliZ deletion greatly reduces gliotoxin production and eliminates the expression of some other gli cluster genes (e.g., gliI, gliA, gliG) but not gliT (encoding a thioredoxin reductase that protects the fungus from gliotoxin) [101,102]. Interestingly, gliT is under the regulation of RgIT, another PSTF regulating the gli BGC but located outside of the cluster (Figure $4 \mathrm{~b}$ ) [86]. RglT regulates the expression of gliF, gliM, gliT, and gliA as well as gtmA (not in gli cluster) in the presence of allyl alcohol and of $g l i Z$, gliT, and gliF under the gliotoxin-inducing conditions through directly binding to these gene promoter regions [86]. The $\Delta r g l T$ strain cannot produce gliotoxin, indicating that RglT is essential for the gliotoxin biosynthesis. RglT mediates A. fumigatus selfprotection against exogenous gliotoxin, probably through the expression of gliT and the bisthiomethyltransferase-encoding gene $\operatorname{gtm} A$. This gives an example of a single BGC containing one in-cluster PSTF and another out-of-cluster PSTF, both involved in virulence but only one activating self-protection mechanisms.

\section{Pathway Specific Approaches to Explore Biosynthetic Gene Clusters}

A number of useful approaches were developed to activate cryptic BGCs, and the most rapid, easy-handling, and versatile method is to manipulate the PSTF. It often allows for precise, controllable activation of a specific BGC and expectations to unambiguously identify metabolic products.

\subsection{Overexpression/Deletion of PSTF}

Most PSTFs are positive-regulators, while few of them are negative-regulators, as discussed previously. Thus, inducing the expression of pathway specific activator genes and deleting pathway specific repressor genes are both promising approaches for activating cryptic BGCs [103]. To overexpress positive acting PSTFs, replacing the native promoter with a constitutive promoter or an inducible promoter is commonly used. For example, overexpression of the PSTF gene $f_{s} q A$ using the constitutive promoter gpdAp from $A$. nidulans upregulated the expression of the $f_{s} q \mathrm{BGC}$ and produced several new isoquinoline alkaloids known as fumisoquins [80]. Activation of the PSTF gene $a p d R$ with the inducible alcohol dehydrogenase promoter alc $A p$ from $A$. nidulans resulted in expression of the apd BGC ( $a p d A, a p d B, a p d C, a p d D, a p d E$, and $a p d G)$ under inducing conditions to produce aspyridones A and B [49].

\subsection{Synthetic PSTF}

The approach of replacing the promoter of PSTF can work spectacularly well, but not always. This might be due to domain function loss of a PSTF, lack of an unknown natural inducer, requirement for a different or second TF, requirement of a specific precursor, or requirement of post-translational modification of a PSTF, among other possibilities [104]. In some cases, synthetic PSTFs circumvented these problems.

\subsubsection{Hybrid PSTF}

For the silent $A$. nidulans BGC containing a highly reducing PKS gene, AN11191, the normal approach of upregulating the cluster PSTF could not activate this gene cluster [36]. Grau et al. [45] built a hybrid PSTF to drive the expression of this cluster successfully. They added an activation domain (AD) from AfoA, the PSTF that drives expression of the asperfuranone gene cluster, to the in-cluster PSTF AlnR. The hybrid PSTF AlnR(5-407)AfoA(130-666) contains the DNA binding domain (DBD), consisting of the $\mathrm{Zn}(\mathrm{II})_{2} \mathrm{Cys}_{6}$ zinc binuclear cluster and the heptad repeats coiled-coil dimerization region, from AlnR and a stable activation domain, which is not precisely defined but is located within residues 130-666 of AfoA. The hybrid PSTF was then driven by inducible promoter alcAp. Under inducing conditions, strong expression of the hybrid PSTF resulted in the activation of $a l n$ genes and production of (+)-asperlin, which is the final product of the aln cluster. 


\subsubsection{CRISPR-Mediated Activation System (Artificial PSTF)}

The versatility and the programmability of Cas9 make the CRISPR/Cas9 genome editing strategy a revolutionary approach in biological research. Cas9 can modulate transcription without editing a genomic sequence by fusing the enzymatically inactive version of Cas9 (dCas9) with a transcriptional activation domain; this is known as a CRISPR-mediated activation system (CRISPRa) [105]. Furthermore, by concurrently expressing multiple gRNAs (guide RNAs, specific for the gene sequence of choice), several genes could be simultaneously activated with multiplexed CRISPRa. In addition to dCas9, dCas12 (previously known as dCpf1) is another construct used in CRISPRa, where strong synthetic VP64-p65-Rta (VPR) activators are incorporated into the technology [106]. Roux et al. [25] constructed and tested both CRISPR/dLbCas12a-VPR-based and CRISPR/dSpCas9a-VPR-based activation systems to induce the mic BGC in A. nidulans. Ultimately, the CRISPR/dLbCas12a-based activation system was successful in the activation of three mic cluster genes to produce the final product, dehydromicroperfuranone.

\section{Conclusions and Perspectives}

By examining characterized BGCs and their PSTFs in A. nidulans and A. fumigatus, we find that the majority of in-cluster PSTFs are positive regulators of BGCs, and overexpression of these PSTFs leads to increased titers of specific BGC products. PSTFs are usually found in larger BGCs, typically with those containing more than five genes. This raises questions to be examined in future studies: how did the need for PSTFs arise in larger clusters, and why do smaller BGCs not require a PSTF? Whereas most PSTFs appear to operate as solo regulators for their localized BGC, some PSTFs interact with other PSTFs for BGC activation (e.g., AflR-AflS and similar dual regulators) or evolve to function in outof-cluster biosynthetic pathways (e.g., PeXanC vs. AfXanC; ScpR; RglT). Understanding and prediction of trans regulatory functions of PSTFs could open new avenues for BGC activation. New strategies are always needed to activate cryptic BGCs and their SM products. A more thorough understanding of PSTF regulatory mechanisms coupled with synergistic development of technologies help to promote the development of pathway specific activation approaches (e.g., synthetic PSTFs and CRISPR-mediated activation systems) can propel advances in this area. The molecular mechanism of PSTF protein-DNA interactions is still limited, and a better understanding of these interactions should also contribute to a useful PSTF toolkit [107]. In our long term goal in synthetic biology, PSTFs would act as the conductor of the engineered orchestra designed to produce new valuable drugs.

Author Contributions: Writing - original draft preparation, W.W.; writing-information collection, Y.Y.; writing-review and editing, N.P.K. and P.W. All authors have read and agreed to the published version of the manuscript.

Funding: This research was funded in part by the National Institutes of Health under grant 2R01GM112739-05A1 to N.P.K. and by the Zhoushan City-Zhejiang University Joint Specific Project under grant 2020C81004 to P.W.

Institutional Review Board Statement: Not applicable.

Informed Consent Statement: Not applicable.

Data Availability Statement: Not applicable.

Conflicts of Interest: The authors declare no conflict of interest.

\section{References}

1. Robey, M.T.; Caesar, L.K.; Drott, M.T.; Keller, N.P.; Kelleher, N.L. An interpreted atlas of biosynthetic gene clusters from 1000 fungal genomes. Proc. Natl. Acad. Sci. USA 2021, 118, e2020230118. [CrossRef]

2. Keller, N.P. Translating biosynthetic gene clusters into fungal armor and weaponry. Nat. Chem. Biol. 2015, 11, 671-677. [CrossRef] [PubMed]

3. Macheleidt, J.; Mattern, D.J.; Fischer, J.; Netzker, T.; Weber, J.; Schroeckh, V.; Valiante, V.; Brakhage, A.A. Regulation and role of fungal secondary metabolites. Annu. Rev. Genet. 2016, 50, 371-392. [CrossRef] 
4. Keller, N.P. Fungal secondary metabolism: Regulation, function and drug discovery. Nat. Rev. Microbiol. 2019, 17, 167-180. [CrossRef] [PubMed]

5. Sbaraini, N.; Hu, J.; Roux, I.; Phan, C.S.; Motta, H.; Rezaee, H.; Schrank, A.; Chooi, Y.H.; Staats, C.C. Polyketides produced by the entomopathogenic fungus Metarhizium anisopliae induce Candida albicans growth. Fungal Genet. Biol. 2021, $152,103568$. [CrossRef]

6. Lim, S.; Bijlani, S.; Blachowicz, A.; Chiang, Y.-M.; Lee, M.-S.; Torok, T.; Venkateswaran, K.; Wang, C.C.C. Identification of the pigment and its role in UV resistance in Paecilomyces variotii, a Chernobyl isolate, using genetic manipulation strategies. Fungal Genet. Biol. 2021, 152, 103567. [CrossRef] [PubMed]

7. Boruta, T. Uncovering the repertoire of fungal secondary metabolites: From Fleming's laboratory to the International Space Station. Bioengineered 2018, 9, 12-16. [CrossRef] [PubMed]

8. Khan, A.A.; Bacha, N.; Ahmad, B.; Lutfullah, G.; Farooq, U.; Cox, R.J. Fungi as chemical industries and genetic engineering for the production of biologically active secondary metabolites. Asian Pac. J. Trop. Biomed. 2014, 4, 859-870. [CrossRef]

9. Roy, A.; Ahuja, S.; Garg, S. Fungal secondary metabolites: Biological activity and potential applications. In Recent Trends in Mycological Research: Volume 1: Agricultural and Medical Perspective; Yadav, A.N., Ed.; Springer International Publishing: Cham, Switzerland, 2021; pp. 159-188.

10. Florey, H.W. Penicillin: A survey. Br. Med. J. 1944, 2, 169-171. [CrossRef]

11. Anjum, T.; Azam, A.; Irum, W. Production of cyclosporine A by submerged fermentation from a local isolate of Penicillium fellutanum. Indian J. Pharm. Sci. 2012, 74, 372-374. [CrossRef]

12. Endo, A. A historical perspective on the discovery of statins. Proc. Jpn. Acad. Ser. B Phys. Biol. Sci. 2010, 86, 484-493. [CrossRef]

13. Tsunematsu, Y. Genomics-directed activation of cryptic natural product pathways deciphers codes for biosynthesis and molecular function. J. Nat. Med. 2021, 75, 261-274. [CrossRef]

14. Greco, C.; Keller, N.P.; Rokas, A. Unearthing fungal chemodiversity and prospects for drug discovery. Curr. Opin. Microbiol. 2019, 51, 22-29. [CrossRef] [PubMed]

15. Kjaerbolling, I.; Mortensen, U.H.; Vesth, T.; Andersen, M.R. Strategies to establish the link between biosynthetic gene clusters and secondary metabolites. Fungal Genet. Biol. 2019, 130, 107-121. [CrossRef] [PubMed]

16. Lim, F.Y.; Won, T.H.; Raffa, N.; Baccile, J.A.; Wisecaver, J.; Rokas, A.; Schroeder, F.C.; Keller, N.P. Fungal isocyanide synthases and xanthocillin biosynthesis in Aspergillus fumigatus. mBio 2018, 9, e00785-18. [CrossRef] [PubMed]

17. Garcia-Estrada, C.; Dominguez-Santos, R.; Kosalkova, K.; Martin, J.F. Transcription factors controlling primary and secondary metabolism in filamentous fungi: The beta-Lactam paradigm. Fermentation 2018, 4, 47. [CrossRef]

18. Yin, W.; Keller, N.P. Transcriptional regulatory elements in fungal secondary metabolism. J. Microbiol. 2011, 49, 329-339. [CrossRef]

19. Shelest, E. Transcription factors in fungi. FEMS Microbiol. Lett. 2008, 286, 145-151. [CrossRef]

20. Park, H.S.; Bayram, O.; Braus, G.H.; Kim, S.C.; Yu, J.H. Characterization of the velvet regulators in Aspergillus fumigatus. Mol. Microbiol. 2012, 86, 937-953. [CrossRef] [PubMed]

21. Ahmed, Y.L.; Gerke, J.; Park, H.-S.; Bayram, Ö.; Neumann, P.; Ni, M.; Dickmanns, A.; Kim, S.C.; Yu, J.-H.; Braus, G.H.; et al. The velvet family of fungal regulators contains a DNA-binding domain structurally similar to NF-kB. PLoS Biol. 2013, 11, e1001750. [CrossRef]

22. Li, B.; Chen, Y.; Tian, S. Function of pH-dependent transcription factor PacC in regulating development, pathogenicity, and mycotoxin biosynthesis of phytopathogenic fungi. FEBS J. 2021, 15808. [CrossRef] [PubMed]

23. Bok, J.W.; Chiang, Y.M.; Szewczyk, E.; Reyes-Dominguez, Y.; Davidson, A.D.; Sanchez, J.F.; Lo, H.C.; Watanabe, K.; Strauss, J.; Oakley, B.R.; et al. Chromatin-level regulation of biosynthetic gene clusters. Nat. Chem. Biol. 2009, 5, 462-464. [CrossRef]

24. Pfannenstiel, B.T.; Keller, N.P. On top of biosynthetic gene clusters: How epigenetic machinery influences secondary metabolism in fungi. Biotechnol. Adv. 2019, 37, 107345. [CrossRef]

25. Roux, I.; Woodcraft, C.; Hu, J.; Wolters, R.; Gilchrist, C.L.M.; Chooi, Y.H. CRISPR-mediated activation of biosynthetic gene clusters for bioactive molecule discovery in filamentous fungi. ACS Synth. Biol. 2020, 9, 1843-1854. [CrossRef]

26. Caesar, L.K.; Kelleher, N.L.; Keller, N.P. In the fungus where it happens: History and future propelling Aspergillus nidulans as the archetype of natural products research. Fungal Genet. Biol. 2020, 144, 103477. [CrossRef] [PubMed]

27. Romsdahl, J.; Wang, C.C.C. Recent advances in the genome mining of Aspergillus secondary metabolites (covering 2012-2018). Medchemcomm 2019, 10, 840-866. [CrossRef]

28. Stroe, M.C.; Netzker, T.; Scherlach, K.; Kruger, T.; Hertweck, C.; Valiante, V.; Brakhage, A.A. Targeted induction of a silent fungal gene cluster encoding the bacteria-specific germination inhibitor fumigermin. Elife 2020, 9, e52541. [CrossRef] [PubMed]

29. Ma, K.; Zhang, P.; Tao, Q.; Keller, N.P.; Yang, Y.; Yin, W.B.; Liu, H. Characterization and biosynthesis of a rare fungal hopane-type triterpenoid glycoside involved in the antistress property of Aspergillus fumigatus. Org. Lett. 2019, 21, 3252-3256. [CrossRef] [PubMed]

30. Schmaler-Ripcke, J.; Sugareva, V.; Gebhardt, P.; Winkler, R.; Kniemeyer, O.; Heinekamp, T.; Brakhage, A.A. Production of pyomelanin, a second type of melanin, via the tyrosine degradation pathway in Aspergillus fumigatus. Appl. Environ. Microbiol. 2009, 75, 493-503. [CrossRef]

31. Yeh, H.H.; Ahuja, M.; Chiang, Y.M.; Oakley, C.E.; Moore, S.; Yoon, O.; Hajovsky, H.; Bok, J.W.; Keller, N.P.; Wang, C.C.; et al Resistance gene-guided genome mining: Serial promoter exchanges in Aspergillus nidulans reveal the biosynthetic pathway for fellutamide B, a proteasome inhibitor. ACS Chem. Biol. 2016, 11, 2275-2284. [CrossRef] 
32. Li, S.M.; Unsold, I.A. Post-genome research on the biosynthesis of ergot alkaloids. Planta Med. 2006, 72, 1117-1120. [CrossRef]

33. O'Hanlon, K.A.; Gallagher, L.; Schrettl, M.; Jochl, C.; Kavanagh, K.; Larsen, T.O.; Doyle, S. Nonribosomal peptide synthetase genes pesL and pes1 are essential for Fumigaclavine C production in Aspergillus fumigatus. Appl. Environ. Microbiol. 2012, 78, 3166-3176. [CrossRef]

34. Westphal, K.R.; Muurmann, A.T.; Paulsen, I.E.; Nørgaard, K.T.H.; Overgaard, M.L.; Dall, S.M.; Aalborg, T.; Wimmer, R.; Sørensen, J.L.; Sondergaard, T.E. Who needs neighbors? PKS8 Is a stand-alone gene in Fusarium graminearum responsible for production of gibepyrones and prolipyrone B. Molecules 2018, 23, 2232. [CrossRef] [PubMed]

35. Dean, R.A. Fungal gene clusters. Nat. Biotechnol. 2007, 25, 67. [CrossRef] [PubMed]

36. Ahuja, M.; Chiang, Y.M.; Chang, S.L.; Praseuth, M.B.; Entwistle, R.; Sanchez, J.F.; Lo, H.C.; Yeh, H.H.; Oakley, B.R.; Wang, C.C. Illuminating the diversity of aromatic polyketide synthases in Aspergillus nidulans. J. Am. Chem. Soc. 2012, 134, 8212-8221. [CrossRef] [PubMed]

37. Cary, J.W.; Ehrlich, K.C. Aflatoxigenicity in Aspergillus: Molecular genetics, phylogenetic relationships and evolutionary implications. Mycopathologia 2006, 162, 167-177. [CrossRef] [PubMed]

38. Calvo, A.M.; Dhingra, S. Conserved regulatory mechanisms controlling aflatoxin and sterigmatocystin biosynthesis. In Aflatoxins: Biochemistry and Molecular Biology; Intech Open: Rijeka, Croatia, 2011; pp. 67-88.

39. Oakley, C.E.; Ahuja, M.; Sun, W.W.; Entwistle, R.; Akashi, T.; Yaegashi, J.; Guo, C.J.; Cerqueira, G.C.; Russo Wortman, J.; Wang, C.C.; et al. Discovery of McrA, a master regulator of Aspergillus secondary metabolism. Mol. Microbiol. 2017, 103, 347-365. [CrossRef]

40. Gerke, J.; Bayram, O.; Feussner, K.; Landesfeind, M.; Shelest, E.; Feussner, I.; Braus, G.H. Breaking the silence: Protein stabilization uncovers silenced biosynthetic gene clusters in the fungus Aspergillus nidulans. Appl. Environ. Microbiol. 2012, 78, 8234-8244. [CrossRef]

41. Chiang, Y.M.; Ahuja, M.; Oakley, C.E.; Entwistle, R.; Asokan, A.; Zutz, C.; Wang, C.C.; Oakley, B.R. Development of genetic dereplication strains in Aspergillus nidulans results in the discovery of aspercryptin. Angew. Chem. Int. Ed. Engl. 2016, 55, 1662-1665. [CrossRef]

42. Henke, M.T.; Soukup, A.A.; Goering, A.W.; McClure, R.A.; Thomson, R.J.; Keller, N.P.; Kelleher, N.L. New aspercryptins, lipopeptide natural products, revealed by HDAC inhibition in Aspergillus nidulans. ACS Chem. Biol. 2016, 11, $2117-2123$. [CrossRef]

43. Chiang, Y.M.; Szewczyk, E.; Davidson, A.D.; Keller, N.; Oakley, B.R.; Wang, C.C. A gene cluster containing two fungal polyketide synthases encodes the biosynthetic pathway for a polyketide, asperfuranone, in Aspergillus nidulans. J. Am. Chem. Soc. 2009, 131, 2965-2970. [CrossRef]

44. Bergmann, S.; Funk, A.N.; Scherlach, K.; Schroeckh, V.; Shelest, E.; Horn, U.; Hertweck, C.; Brakhage, A.A. Activation of a silent fungal polyketide biosynthesis pathway through regulatory cross talk with a cryptic nonribosomal peptide synthetase gene cluster. Appl. Environ. Microbiol. 2010, 76, 8143-8149. [CrossRef]

45. Grau, M.F.; Entwistle, R.; Chiang, Y.M.; Ahuja, M.; Oakley, C.E.; Akashi, T.; Wang, C.C.C.; Todd, R.B.; Oakley, B.R. Hybrid transcription factor engineering activates the silent secondary metabolite gene cluster for (+)-asperlin in Aspergillus nidulans. ACS Chem. Biol. 2018, 3, 3193-3205. [CrossRef]

46. Yaegashi, J.; Praseuth, M.B.; Tyan, S.W.; Sanchez, J.F.; Entwistle, R.; Chiang, Y.M.; Oakley, B.R.; Wang, C.C. Molecular genetic characterization of the biosynthesis cluster of a prenylated isoindolinone alkaloid aspernidine A in Aspergillus nidulans. Org. Lett. 2013, 15, 2862-2865. [CrossRef]

47. Lin, T.S.; Chen, B.; Chiang, Y.M.; Wang, C.C.C. Discovery and elucidation of the biosynthesis of aspernidgulenes: Novel polyenes from Aspergillus nidulans by using serial promoter replacement. Chembiochem 2019, 20, 329-334. [CrossRef]

48. Szewczyk, E.; Chiang, Y.M.; Oakley, C.E.; Davidson, A.D.; Wang, C.C.; Oakley, B.R. Identification and characterization of the asperthecin gene cluster of Aspergillus nidulans. Appl. Environ. Microbiol. 2008, 74, 7607-7612. [CrossRef]

49. Bergmann, S.; Schumann, J.; Scherlach, K.; Lange, C.; Brakhage, A.A.; Hertweck, C. Genomics-driven discovery of PKS-NRPS hybrid metabolites from Aspergillus nidulans. Nat. Chem. Biol. 2007, 3, 213-217. [CrossRef]

50. Lo, H.C.; Entwistle, R.; Guo, C.J.; Ahuja, M.; Szewczyk, E.; Hung, J.H.; Chiang, Y.M.; Oakley, B.R.; Wang, C.C. Two separate gene clusters encode the biosynthetic pathway for the meroterpenoids austinol and dehydroaustinol in Aspergillus nidulans. J. Am. Chem. Soc. 2012, 134, 4709-4720. [CrossRef] [PubMed]

51. Sanchez, J.F.; Entwistle, R.; Corcoran, D.; Oakley, B.R.; Wang, C.C. Identification and molecular genetic analysis of the cichorine gene cluster in Aspergillus nidulans. Medchemcomm 2012, 3, 997-1002. [CrossRef] [PubMed]

52. Huttel, W.; Youssar, L.; Gruning, B.A.; Gunther, S.; Hugentobler, K.G. Echinocandin B biosynthesis: A biosynthetic cluster from Aspergillus nidulans NRRL 8112 and reassembly of the subclusters Ecd and Hty from Aspergillus pachycristatus NRRL 11440 reveals a single coherent gene cluster. BMC Genom. 2016, 17, 570. [CrossRef] [PubMed]

53. Chiang, Y.M.; Szewczyk, E.; Nayak, T.; Davidson, A.D.; Sanchez, J.F.; Lo, H.C.; Ho, W.Y.; Simityan, H.; Kuo, E.; Praseuth, A.; et al. Molecular genetic mining of the Aspergillus secondary metabolome: Discovery of the emericellamide biosynthetic pathway. Chem. Biol. 2008, 15, 527-532. [CrossRef]

54. Bromann, K.; Toivari, M.; Viljanen, K.; Vuoristo, A.; Ruohonen, L.; Nakari-Setala, T. Identification and characterization of a novel diterpene gene cluster in Aspergillus nidulans. PLoS ONE 2012, 7, e35450. [CrossRef] 
55. Sanchez, J.F.; Chiang, Y.M.; Szewczyk, E.; Davidson, A.D.; Ahuja, M.; Elizabeth Oakley, C.; Woo Bok, J.; Keller, N.; Oakley, B.R.; Wang, C.C. Molecular genetic analysis of the orsellinic acid/F9775 gene cluster of Aspergillus nidulans. Mol. Biosyst. 2010, 6, 587-593. [CrossRef] [PubMed]

56. Nielsen, M.L.; Nielsen, J.B.; Rank, C.; Klejnstrup, M.L.; Holm, D.K.; Brogaard, K.H.; Hansen, B.G.; Frisvad, J.C.; Larsen, T.O.; Mortensen, U.H. A genome-wide polyketide synthase deletion library uncovers novel genetic links to polyketides and meroterpenoids in Aspergillus nidulans. FEMS Microbiol. Lett. 2011, 321, 157-166. [CrossRef] [PubMed]

57. Eisendle, M.; Oberegger, H.; Zadra, I.; Haas, H. The siderophore system is essential for viability of Aspergillus nidulans: Functional analysis of two genes encoding L-ornithine $\mathrm{N}^{5}$-monooxygenase (sidA) and a non-ribosomal peptide synthetase (sidC). Mol. Microbiol. 2003, 49, 359-375. [CrossRef] [PubMed]

58. Sung, C.T.; Chang, S.L.; Entwistle, R.; Ahn, G.; Lin, T.S.; Petrova, V.; Yeh, H.H.; Praseuth, M.B.; Chiang, Y.M.; Oakley, B.R.; et al. Overexpression of a three-gene conidial pigment biosynthetic pathway in Aspergillus nidulans reveals the first NRPS known to acetylate tryptophan. Fungal Genet. Biol. 2017, 101, 1-6. [CrossRef] [PubMed]

59. Ishikawa, N.; Tanaka, H.; Koyama, F.; Noguchi, H.; Wang, C.C.; Hotta, K.; Watanabe, K. Non-heme dioxygenase catalyzes atypical oxidations of 6,7-bicyclic systems to form the 6,6-quinolone core of viridicatin-type fungal alkaloids. Angew. Chem. Int. Ed. Engl. 2014, 53, 12880-12884. [CrossRef]

60. Yeh, H.H.; Chiang, Y.M.; Entwistle, R.; Ahuja, M.; Lee, K.H.; Bruno, K.S.; Wu, T.K.; Oakley, B.R.; Wang, C.C. Molecular genetic analysis reveals that a nonribosomal peptide synthetase-like (NRPS-like) gene in Aspergillus nidulans is responsible for microperfuranone biosynthesis. Appl. Microbiol. Biotechnol. 2012, 96, 739-748. [CrossRef]

61. Sanchez, J.F.; Entwistle, R.; Hung, J.H.; Yaegashi, J.; Jain, S.; Chiang, Y.M.; Wang, C.C.; Oakley, B.R. Genome-based deletion analysis reveals the prenyl xanthone biosynthesis pathway in Aspergillus nidulans. J. Am. Chem. Soc. 2011, 133, $4010-4017$. [CrossRef]

62. Chiang, Y.M.; Szewczyk, E.; Davidson, A.D.; Entwistle, R.; Keller, N.P.; Wang, C.C.; Oakley, B.R. Characterization of the Aspergillus nidulans monodictyphenone gene cluster. Appl. Environ. Microbiol. 2010, 76, 2067-2074. [CrossRef]

63. Scherlach, K.; Sarkar, A.; Schroeckh, V.; Dahse, H.M.; Roth, M.; Brakhage, A.A.; Horn, U.; Hertweck, C. Two induced fungal polyketide pathways converge into antiproliferative spiroanthrones. Chembiochem 2011, 12, 1836-1839. [CrossRef]

64. Andersen, M.R.; Nielsen, J.B.; Klitgaard, A.; Petersen, L.M.; Zachariasen, M.; Hansen, T.J.; Blicher, L.H.; Gotfredsen, C.H.; Larsen, T.O.; Nielsen, K.F.; et al. Accurate prediction of secondary metabolite gene clusters in filamentous fungi. Proc. Natl. Acad. Sci. USA 2013, 110, E99-E107. [CrossRef]

65. Bergh, K.T.; Brakhage, A.A. Regulation of the Aspergillus nidulans penicillin biosynthesis gene acvA (pcbAB) by amino acids: Implication for involvement of transcription factor PACC. Appl. Environ. Microbiol. 1998, 64, 843-849. [CrossRef]

66. Bouhired, S.; Weber, M.; Kempf-Sontag, A.; Keller, N.P.; Hoffmeister, D. Accurate prediction of the Aspergillus nidulans terrequinone gene cluster boundaries using the transcriptional regulator LaeA. Fungal. Genet. Biol. 2007, 44, 1134-1145. [CrossRef]

67. Chooi, Y.H.; Cacho, R.; Tang, Y. Identification of the viridicatumtoxin and griseofulvin gene clusters from Penicillium aethiopicum. Chem. Biol. 2010, 17, 483-494. [CrossRef]

68. Drott, M.T.; Bastos, R.W.; Rokas, A.; Ries, L.N.A.; Gabaldon, T.; Goldman, G.H.; Keller, N.P.; Greco, C. Diversity of secondary metabolism in Aspergillus nidulans clinical isolates. mSphere 2020, 5, e00156-20. [CrossRef] [PubMed]

69. Mayorga, M.E.; Timberlake, W.E. Isolation and molecular characterization of the Aspergillus nidulans wA gene. Genetics 1990, 126, 73-79. [CrossRef]

70. Tsai, H.F.; Wheeler, M.H.; Chang, Y.C.; Kwon-Chung, K.J. A developmentally regulated gene cluster involved in conidial pigment biosynthesis in Aspergillus fumigatus. J. Bacteriol. 1999, 181, 6469-6477. [CrossRef] [PubMed]

71. Bayry, J.; Beaussart, A.; Dufrene, Y.F.; Sharma, M.; Bansal, K.; Kniemeyer, O.; Aimanianda, V.; Brakhage, A.A.; Kaveri, S.V.; Kwon-Chung, K.J.; et al. Surface structure characterization of Aspergillus fumigatus conidia mutated in the melanin synthesis pathway and their human cellular immune response. Infect. Immun. 2014, 82, 3141-3153. [CrossRef]

72. Throckmorton, K.; Lim, F.Y.; Kontoyiannis, D.P.; Zheng, W.; Keller, N.P. Redundant synthesis of a conidial polyketide by two distinct secondary metabolite clusters in Aspergillus fumigatus. Environ. Microbiol. 2016, 18, 246-259. [CrossRef] [PubMed]

73. Blatzer, M.; Schrettl, M.; Sarg, B.; Lindner, H.H.; Pfaller, K.; Haas, H. SidL, an Aspergillus fumigatus transacetylase involved in biosynthesis of the siderophores ferricrocin and hydroxyferricrocin. Appl. Environ. Microb. 2011, 77, 4959-4966. [CrossRef]

74. Schrettl, M.; Kim, H.S.; Eisendle, M.; Kragl, C.; Nierman, W.C.; Heinekamp, T.; Werner, E.R.; Jacobsen, I.; Illmer, P.; Yi, H.; et al. SreA-mediated iron regulation in Aspergillus fumigatus. Mol. Microbiol. 2008, 70, 27-43. [CrossRef]

75. Lin, H.C.; Chooi, Y.H.; Dhingra, S.; Xu, W.; Calvo, A.M.; Tang, Y. The fumagillin biosynthetic gene cluster in Aspergillus fumigatus encodes a cryptic terpene cyclase involved in the formation of $\beta$-trans-bergamotene. J. Am. Chem. Soc. 2013, 135, 4616-4619. [CrossRef] [PubMed]

76. Dhingra, S.; Lind, A.L.; Lin, H.C.; Tang, Y.; Rokas, A.; Calvo, A.M. The fumagillin gene cluster, an example of hundreds of genes under veA control in Aspergillus fumigatus. PLOS ONE 2013, 8, e77147. [CrossRef]

77. Wiemann, P.; Guo, C.J.; Palmer, J.M.; Sekonyela, R.; Wang, C.C.; Keller, N.P. Prototype of an intertwined secondary-metabolite supercluster. Proc. Natl. Acad. Sci. USA 2013, 110, 17065-17070. [CrossRef] [PubMed]

78. Ames, B.D.; Haynes, S.W.; Gao, X.; Evans, B.S.; Kelleher, N.L.; Tang, Y.; Walsh, C.T. Complexity generation in fungal peptidyl alkaloid biosynthesis: Oxidation of fumiquinazoline A to the heptacyclic hemiaminal fumiquinazoline $\mathrm{C}$ by the flavoenzyme Af12070 from Aspergillus fumigatus. Biochemistry 2011, 50, 8756-8769. [CrossRef] 
79. Macheleidt, J.; Scherlach, K.; Neuwirth, T.; Schmidt-Heck, W.; Straßburger, M.; Spraker, J.; Baccile, J.A.; Schroeder, F.C.; Keller, N.P.; Hertweck, C.; et al. Transcriptome analysis of cyclic AMP-dependent protein kinase A-regulated genes reveals the production of the novel natural compound fumipyrrole by Aspergillus fumigatus. Mol. Microbiol. 2015, 96, 148-162. [CrossRef] [PubMed]

80. Baccile, J.A.; Spraker, J.E.; Le, H.H.; Brandenburger, E.; Gomez, C.; Bok, J.W.; Macheleidt, J.; Brakhage, A.A.; Hoffmeister, D.; Keller, N.P.; et al. Plant-like biosynthesis of isoquinoline alkaloids in Aspergillus fumigatus. Nat. Chem. Biol. 2016, 12, 419-424. [CrossRef] [PubMed]

81. Maiya, S.; Grundmann, A.; Li, S.M.; Turner, G. The fumitremorgin gene cluster of Aspergillus fumigatus: Identification of a gene encoding brevianamide F synthetase. Chembiochem 2006, 7, 1062-1069. [CrossRef] [PubMed]

82. Kato, N.; Suzuki, H.; Takagi, H.; Asami, Y.; Kakeya, H.; Uramoto, M.; Usui, T.; Takahashi, S.; Sugimoto, Y.; Osada, H. Identification of cytochrome P450s required for fumitremorgin biosynthesis in Aspergillus fumigatus. Chembiochem 2009, 10, 920-928. [CrossRef]

83. Gardiner, D.M.; Howlett, B.J. Bioinformatic and expression analysis of the putative gliotoxin biosynthetic gene cluster of Aspergillus fumigatus. FEMS Microbiol. Lett. 2005, 248, 241-248. [CrossRef]

84. Gardiner, D.M.; Waring, P.; Howlett, B.J. The epipolythiodioxopiperazine (ETP) class of fungal toxins: Distribution, mode of action, functions and biosynthesis. Microbiology 2005, 151, 1021-1032. [CrossRef]

85. Forseth, R.R.; Fox, E.M.; Chung, D.; Howlett, B.J.; Keller, N.P.; Schroeder, F.C. Identification of cryptic products of the gliotoxin gene cluster using NMR-based comparative metabolomics and a model for gliotoxin biosynthesis. J. Am. Chem. Soc. 2011, 133, 9678-9681. [CrossRef]

86. Ries, L.N.A.; Pardeshi, L.; Dong, Z.L.; Tan, K.; Steenwyk, J.L.; Colabardini, A.C.; Ferreira, J.A.; de Castro, P.A.; Silva, L.P.; Preite, N.W.; et al. The Aspergillus fumigatus transcription factor RglT is important for gliotoxin biosynthesis and self-protection, and virulence. PLoS Pathog. 2020, 16, e1008645. [CrossRef]

87. Lv, J.M.; Hu, D.; Gao, H.; Kushiro, T.; Awakawa, T.; Chen, G.D.; Wang, C.X.; Abe, I.; Yao, X.S. Biosynthesis of helvolic acid and identification of an unusual C-4-demethylation process distinct from sterol biosynthesis. Nat. Commun. 2017, 8, 1644. [CrossRef]

88. Yin, W.B.; Baccile, J.A.; Bok, J.W.; Chen, Y.; Keller, N.P.; Schroeder, F.C. A nonribosomal peptide synthetase-derived iron(III) complex from the pathogenic fungus Aspergillus fumigatus. J. Am. Chem. Soc. 2013, 135, 2064-2067. [CrossRef] [PubMed]

89. Chooi, Y.H.; Wang, P.; Fang, J.; Li, Y.; Wu, K.; Wang, P.; Tang, Y. Discovery and characterization of a group of fungal polycyclic polyketide prenyltransferases. J. Am. Chem. Soc. 2012, 134, 9428-9437. [CrossRef] [PubMed]

90. Konig, C.C.; Scherlach, K.; Schroeckh, V.; Horn, F.; Nietzsche, S.; Brakhage, A.A.; Hertweck, C. Bacterium induces cryptic meroterpenoid pathway in the pathogenic fungus Aspergillus fumigatus. Chembiochem 2013, 14, 938-942. [CrossRef] [PubMed]

91. Chooi, Y.H.; Fang, J.; Liu, H.; Filler, S.G.; Wang, P.; Tang, Y. Genome mining of a prenylated and immunosuppressive polyketide from pathogenic fungi. Org. Lett. 2013, 15, 780-783. [CrossRef] [PubMed]

92. Vodisch, M.; Scherlach, K.; Winkler, R.; Hertweck, C.; Braun, H.P.; Roth, M.; Haas, H.; Werner, E.R.; Brakhage, A.A.; Kniemeyer, O. Analysis of the Aspergillus fumigatus proteome reveals metabolic changes and the activation of the pseurotin A biosynthesis gene cluster in response to hypoxia. J. Proteome. Res. 2011, 10, 2508-2524. [CrossRef]

93. Keller, S.; Macheleidt, J.; Scherlach, K.; Schmaler-Ripcke, J.; Jacobsen, I.D.; Heinekamp, T.; Brakhage, A.A. Pyomelanin formation in Aspergillus fumigatus requires $\mathrm{HmgX}$ and the transcriptional activator HmgR but is dispensable for virulence. PLoS ONE 2011, 6, e26604. [CrossRef]

94. Itoh, T.; Tokunaga, K.; Matsuda, Y.; Fujii, I.; Abe, I.; Ebizuka, Y.; Kushiro, T. Reconstitution of a fungal meroterpenoid biosynthesis reveals the involvement of a novel family of terpene cyclases. Nat. Chem. 2010, 2, 858-864. [CrossRef]

95. Wang, W.; Drott, M.; Greco, C.; Luciano-Rosario, D.; Wang, P.; Keller, N.P. Transcription factor repurposing offers insights into evolution of biosynthetic gene cluster regulation. mBio 2021, e01399-21. [CrossRef]

96. Yu, J.; Chang, P.K.; Ehrlich, K.C.; Cary, J.W.; Bhatnagar, D.; Cleveland, T.E.; Payne, G.A.; Linz, J.E.; Woloshuk, C.P.; Bennett, J.W. Clustered pathway genes in aflatoxin biosynthesis. Appl. Environ. Microbiol. 2004, 70, 1253-1262. [CrossRef]

97. Yu, J.H.; Butchko, R.A.; Fernandes, M.; Keller, N.P.; Leonard, T.J.; Adams, T.H. Conservation of structure and function of the aflatoxin regulatory gene aflR from Aspergillus nidulans and A. flavus. Curr. Genet. 1996, 29, 549-555. [CrossRef] [PubMed]

98. Chang, P.K. Lack of interaction between AFLR and AFLJ contributes to nonaflatoxigenicity of Aspergillus sojae. J. Biotechnol. 2004, 107, 245-253. [CrossRef] [PubMed]

99. Perrin, R.M.; Fedorova, N.D.; Bok, J.W.; Cramer, R.A.; Wortman, J.R.; Kim, H.S.; Nierman, W.C.; Keller, N.P. Transcriptional regulation of chemical diversity in Aspergillus fumigatus by LaeA. PLoS Pathog. 2007, 3, e50. [CrossRef] [PubMed]

100. Knowles, S.L.; Mead, M.E.; Silva, L.P.; Raja, H.A.; Steenwyk, J.L.; Goldman, G.H.; Oberlies, N.H.; Rokas, A. Gliotoxin, a known virulence factor in the major human pathogen Aspergillus fumigatus, is also biosynthesized by its nonpathogenic relative Aspergillus fischeri. mBio 2020, 11, e03361-19. [CrossRef]

101. Bok, J.W.; Chung, D.; Balajee, S.A.; Marr, K.A.; Andes, D.; Nielsen, K.F.; Frisvad, J.C.; Kirby, K.A.; Keller, N.P. GliZ, a transcriptional regulator of gliotoxin biosynthesis, contributes to Aspergillus fumigatus virulence. Infect. Immun. 2006, 74, 6761-6768. [CrossRef]

102. Schrettl, M.; Carberry, S.; Kavanagh, K.; Haas, H.; Jones, G.W.; O’Brien, J.; Nolan, A.; Stephens, J.; Fenelon, O.; Doyle, S. Self-protection against gliotoxin-A component of the gliotoxin biosynthetic cluster, GliT, completely protects Aspergillus fumigatus against exogenous gliotoxin. PLoS Pathog. 2010, 6, e1000952. [CrossRef]

103. Rutledge, P.J.; Challis, G.L. Discovery of microbial natural products by activation of silent biosynthetic gene clusters. Nat. Rev. Microbiol. 2015, 13, 509-523. [CrossRef] [PubMed] 
104. Shimizu, K.; Hicks, J.K.; Huang, T.P.; Keller, N.P. Pka, Ras and RGS protein interactions regulate activity of AflR, a Zn(II) ${ }_{2}$ Cys 6 transcription factor in Aspergillus nidulans. Genetics 2003, 165, 1095-1104. [CrossRef] [PubMed]

105. McCarty, N.S.; Graham, A.E.; Studena, L.; Ledesma-Amaro, R. Multiplexed CRISPR technologies for gene editing and transcriptional regulation. Nat. Commun. 2020, 11, 1281. [CrossRef] [PubMed]

106. Tak, Y.E.; Kleinstiver, B.P.; Nunez, J.K.; Hsu, J.Y.; Horng, J.E.; Gong, J.Y.; Weissman, J.S.; Joung, J.K. Inducible and multiplex gene regulation using CRISPR-Cpf1-based transcription factors. Nat. Methods 2017, 14, 1163. [CrossRef]

107. Castellanos, M.; Mothi, N.; Munoz, V. Eukaryotic transcription factors can track and control their target genes using DNA antennas. Nat. Commun. 2020, 11, 540. [CrossRef] [PubMed] 